\title{
PROTOTYPE LAMPU PENERANGAN PERSAWAHAN OTOMATIS MENGGUNAKAN SOLAR CELL DAN SENSOR CAHAYA
}

\author{
Nadiyah Rahayu ${ }^{1}$, Dimas Fanny Hebrasianto Permadi ${ }^{2}$ \\ 1,2 Jurusan Sistem Komputer, Universitas Islam Balitar \\ ${ }^{1}$ nadiarahayu722@gmail.com, ${ }^{2}$ dimas.fanny92@gmail.com
}

\begin{abstract}
Abstrak
Suhu ideal pertumbuhan dan pembentukan sukrosa tebu berkisar antara $24^{\circ} \mathrm{C}-34^{\circ} \mathrm{C}$ dengan perbedaan suhu antara siang dan malam tidak lebih dari $10^{\circ} \mathrm{C}$. Suhu ideal pertumbuhan dan pembentukan sukrosa tebu berkisar antara $24^{\circ} \mathrm{C}-34^{\circ} \mathrm{C}$ dengan perbedaan suhu antara siang dan malam tidak lebih dari $10^{\circ} \mathrm{C}$. Proses penyimpanan sukrosa ini paling efektif dan optimal pada suhu $15^{\circ} \mathrm{C}$. Oleh sebab itu, tebu yang dipanen malam hari berpotensi lebih manis daripada tebu yang dipanen pada siang hari. Kesulitan dalam pemanenan tebu pada malam hari yaitu pada pencahayaannya. Karena pada malam hari, pencahayaan disawah tidak ada sama sekali. Peneliti membuat lampu penerangan otomatis diarea persawahan ini agar dapat membantu petani pada saat memanen tebu pada malam hari. Lampu penerangan ini menggunakan solar cell sebagai sumber energi, sumber energi yang sudah diubah menjadi energi listrik kemudian disimpan dibaterai sebagai cadangan energi. Lampu penerangan ini menggunakan sensor cahaya yang akan otomatis menyala pada saat malam hari dan akan otomatis mati pada siang hari sehingga petani tidak harus menekan tombol ON/OFF saat menyalakan ataupun mematikan lampu. Hasil dari pengujian alat yang telah dilakukan oleh peneliti yaitu lampu led dapat menyala dan mati secara otomatis. Nilai tegangan LDR yang terbaca di arduino $24-800 \Omega$ maka kondisi lampu LED akan mati , dan jika nilai tegangan LDR yang terbaca di arduino 900 - $1024 \Omega$ lampu LED akan menyala. Solar cell dapat mengisi baterai Li-Ion (Lithium-Ion) berjumlah 1-4 buah. Waktu yang paling optimal untuk proses charging solar cell yaitu antara jam 09.00 - jam 15.00.
\end{abstract}

Kata Kunci: Tanaman tebu, Lampu LED, Solar Cell, Sensor LDR, Baterai Li-Ion (Lithium-Ion).

\section{Pendahuluan}

Energi matahari adalah sumber energi yang persediaannya tidak akan pernah habis. Energi matahari dapat dimanfaatkan sebagai sumber energi alternatif yang dapat diubah menjadi energi listik. Alat yang digunakan untuk mengubah energi matahari menjadi energi listrik adalah solar cell. Pemanfaatan energi alternatif ini juga dapat memecahkan masalah yang terjadi di daerahdaerah yang kekurangan pasokan listrik dan daerah yang banyak disinari matahari. Salah satu dari pemanfaatan energi matahari yaitu pada lampu penerangan di area persawahan.

Lampu penerangan di persawahan masih belum begitu banyak digunakan. Lampu penerangan diarea persawahan dapat membantu petani pada saat musim panen tebu. Biasanya panen tebu yang dilakukan dari pagi hari sampai malam hari. Jika terdapat lampu penerangan yang baik, maka dapat membantu penglihatan petani saat melintasi pematang sawah untuk memanggul tebu yang akan dimasukkan ke dalam truk. Dengan demikian, petani akan lebih mudah melintasi pematang sawah sehingga tidak tersandung dan secara tidak langsung lampu penerangan tersebut akan menjadi lampu penerangan diarea persawahan setiap harinya.
Pengaruh suhu pada pertumbuhan dan pembentukan sukrosa tebu cukup tinggi. Suhu ideal bagi tanaman tebu berkisar antara $24^{\circ} \mathrm{C}$ $34^{\circ} \mathrm{C}$ dengan perbedaan suhu antara siang dan malam tidak lebih dari $10^{\circ} \mathrm{C}$. Pembentukan sukrosa terjadi pada siang hari dan akan berjalan lebih optimal pada suhu $30^{\circ} \mathrm{C}$. Sukrosa yang terbentuk akan timbul/disimpan pada batang dimulai dari ruas paling bawah pada malam hari. Proses penyimpanan sukrosa ini paling efektif dan optimal pada suhu $15^{\circ} \mathrm{C}$. Oleh sebab itu, tebu yang dipanen malam hari berpotensi lebih manis daripada tebu yang dipanen pada siang hari.

Keunggulan dari lampu penerangan persawahan otomatis ini dapat menghemat penggunaan listrik PLN karena memakai tenaga matahari sebagai sumber energi dengan memanfaatkan solar cell. Untuk penggunaan sensor LDR sendiri, untuk memudahkan petani dalam menyalakan lampu tanpa harus menekan tombol ON/OFF. Sensor LDR akan membaca cahaya, jika masih ada cahaya lampu akan mati dan jika sudah tidak ada cahaya lampu akan menyala secara otomatis. 


\section{Tinjauan Pustaka}

\subsection{Penelitian Terdahulu}

Bagustianto Ardiyansyah dan Purwono (2015) dengan judul "Mempelajari Pertumbuhan dan Produktivitas Tebu (Saccharum Officinarum. L) dengan Masa Tanam Sama pada Tipologi Lahan Berbeda". Penelitian tersebut mempelajari pertumbuhan dan produktifitas tanaman tebu. Hasil dari penelitian tersebut adalah mempelajari pengelolaan budidaya tebu dan produktivitas di pabrik yang sama di berbagai tipologi dataran rendah irigasi dan lahan kering. Perbedaan dari dua budidaya lahan merupakan aspek pemeliharaan saluran pembuangan. Di sawah irigasi pemeliharaan selokan sangat penting karena jika tidak dilakukan akan mengakibatkan terganggunya memperdalam saluran pembuangan pertumbuhan tebu. Data primer adalah data yang diperoleh dari efek pertumbuhan dan produktivitas tebu yaitu estimasi produksi, tinggi batang, diameter, jumlah segmen batang, jumlah batang, batang berat, dan nilai brix. Pengamatan menunjukkan bahwa kondisi lahan irigasi dan tadah hujan atau lahan kering tidak menunjukkan pengaruh yang berbeda secara signifikan pada variabel tinggi tanaman dan jumlah segmen. Sedangkan waktu yang selaras untuk pabrik tebu dengan penanaman tebu belum maksimal sehingga pertumbuhan tanaman tidak sesuai dengan waktu tanam karena tidak sesuai dengan Typologi tanah. Moh. Imam Arifin (2017) dengan judul "Bentuk Prototype Kontrol Lampu Penerangan Jalan Umum Dengan Sensor Cahaya Berbasis Arduino". Berdasarkan hasil dari penelitian tersebut diketahui bahwa penelitian tersebut bertujuan untuk mengembangkan kontrol penerangan jalan umum yang dapat bekerja secara otomatis dan dapat menghemat pemakaian listrik. Sensor yang digunakan dalam penelitian tersebut adalah sensor Light Dependent Resistor (LDR) yang digunakan sebagai pendeteksi adanya cahaya pada tempat tersebut. Sensor LDR akan mengatur cahaya dari lampu sesuai dengan cahaya yang diterima oleh sensor LDR. Untuk mengatur cahaya dari lampu menggunakan rangkaian dimmer yang dikendalikan oleh Arduino Nano.

Persamaan antara penelitian ini dengan penelitian yang dilakukan oleh Moh. Imam Arifin sebagai berikut. Pertama, sama-sama menciptakan lampu otomatis dengan sensor LDR.

Perbedaan antara penelitian ini dengan penelitian yang dilakukan oleh Moh. Imam Arifin sebagai berikut. Pertama, di dalam penelitian ini menggunakan Arduino, sedangkan pada penelitian yang dilakukan oleh Moh. Imam Arifin menggunakan Arduino Nano. Kedua, di dalam penelitian ini menggunakan solar cell, sedangkan pada penelitian yang dilakukan oleh Moh. Imam
Arifin tidak menggunakan solar cell. Ketiga, di dalam penelitian ini menggunakan baterai sebagai cadangan energi, sedangkan pada penelitian yang dilakukan oleh Moh. Imam Arifin tidak menggunakan baterai.

Bagustianto Ardiyansyah dan Purwono (2015) dengan judul "Mempelajari Pertumbuhan dan Produktivitas Tebu (Saccharum Officinarum. L) dengan Masa Tanam Sama pada Tipologi Lahan Berbeda". Penelitian tersebut mempelajari pertumbuhan dan produktifitas tanaman tebu. Hasil dari penelitian tersebut adalah mempelajari pengelolaan budidaya tebu dan produktivitas di pabrik yang sama di berbagai tipologi dataran rendah irigasi dan lahan kering. Perbedaan dari dua budidaya lahan merupakan aspek pemeliharaan saluran pembuangan. Di sawah irigasi pemeliharaan selokan sangat penting karena jika tidak dilakukan akan mengakibatkan terganggunya memperdalam saluran pembuangan pertumbuhan tebu. Data primer adalah data yang diperoleh dari efek pertumbuhan dan produktivitas tebu yaitu estimasi produksi, tinggi batang, diameter, jumlah segmen batang, jumlah batang, batang berat, dan nilai brix. Pengamatan menunjukkan bahwa kondisi lahan irigasi dan tadah hujan atau lahan kering tidak menunjukkan pengaruh yang berbeda secara signifikan pada variabel tinggi tanaman dan jumlah segmen. Sedangkan waktu yang selaras untuk pabrik tebu dengan penanaman tebu belum maksimal sehingga pertumbuhan tanaman tidak sesuai dengan waktu tanam karena tidak sesuai dengan Typologi tanah.

Persamaan antara penelitian ini dengan penelitian yang dilakukan oleh Bagustianto Ardiyansyah dan Purwono sebagai berikut. Pertama, sama-sama membahas tentang tanaman tebu.

Perbedaan antara penelitian ini dengan penelitian yang dilakukan oleh Bagustianto Ardiyansyah dan Purwono sebagai berikut. Pertama, penelitian ini membuat lampu penerangan otomatis untuk membantu pada saat panen tebu, sedangkan penelitian yang dilakukan oleh Bagustianto Ardiyansyah dan Purwono mempelajari pertumbuhan dan produktifitas tanaman tebu.

Dadan Somadani dan Ade Heri Ginanjar (2018) dengan judul "Prototype Penerangan Jalan Umum (PJU) Pintar Berbasis Arduino Menggunakan Solar Panel, Sensor Hc-Sr04 Dan Sensor Ldr". Penelitian tersebut menciptakan lampu penerangan jalan. Hasil dari penelitian tersebut adalah semakin pesatnya perkembangan di Indonesia menuntut pembangunan infrastruktur yang semakin baik. Salah satu yang menjadi prioritas adalah pembuatan dan perbaikan jalan umum untuk mendukung mobilitas masyarakat yang semakin tinggi akibat kemajuan teknologi transportasi yang berkembang pesat. Salah satu 
perlengkapan jalan yang sangat dibutuhkan adalah Penerangan Jalan Umun (PJU). Dengan di terapkannya penerangan jalan umum pintar dapat mengurangi penggunaan energi listrik karena penerangan jalan umum pintar mengguanakan panel surya sebagai sumber energi yang didapat dari mengubah panas matahari menjadi energi listrik kemudian disimpan pada baterai. Pada kondisi malam hari, lampu akan menyala terang ketika sensor ultrasonik mendeteksi benda dan ketika tidak ada benda, lampu akan menyala redup. Persamaan antara penelitian ini dengan penelitian yang dilakukan oleh Dadan Somadani dan Ade Heri Ginanjar sebagai berikut. Pertama, sama-sama menciptakan lampu penerangan. Kedua berkaitan dengan sensor yang digunakan.

Perbedaan antara penelitian ini dengan penelitian yang dilakukan oleh Dadan Somadani dan Ade Heri Ginanjar sebagai berikut. Pertama, berkaitan dengan lampu penerangan yang diciptakan. Lampu penerangan di dalam penelitian ini khusus untuk penerangan diarea persawahan, sedangkan penelitian yang dilakukan oleh Dadan Somadani dan Ade Heri Ginanjar untuk penerangan jalan umum. Kedua, berkaitan dengan sensor yang digunakan. Sensor didalam penelitian ini menggunakan sensor cahaya, sedangkan penelitian yang dilakukan oleh Dadan Somadani dan Ade Heri Ginanjar menggunakan sensor HcSr04 dan sensor LDR.

\subsection{Tanaman Tebu}

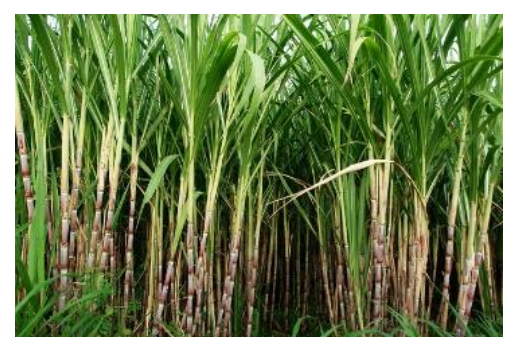

Gambar 1. Tanaman Tebu

Tanaman tebu (Sacharum officinarum L.) tumbuh didaerah tropis dan sub tropis. Kondisi tanah yang baik unuk pertumbuhan tanaman tebu adalah tanah yang tidak terlalu kering dan tanah yang tidak terlalu basah, selain itu akar tanaman tebu sangat sensitif terhadap kekurangan udara dalam tanah sehingga pengairan harus sangat diperhatikan. Suhu ideal bagi tanaman tebu berkisar antara $24^{\circ} \mathrm{C}-34^{\circ} \mathrm{C}$ dengan perbedaan suhu antara siang dan malam tidak lebih dari $10^{\circ} \mathrm{C}$. Pembentukan sukrosa terjadi pada siang hari dan akan berjalan lebih optimal pada suhu $30^{\circ} \mathrm{C}$. Sukrosa yang terbentuk akan timbul/disimpan pada batang dimulai dari ruas paling bawah pada malam hari. Proses penyimpanan sukrosa ini paling efektif dan optimal pada suhu $15^{\circ} \mathrm{C}$. (Siswanto, 2012)

\subsection{Sensor Cahaya}

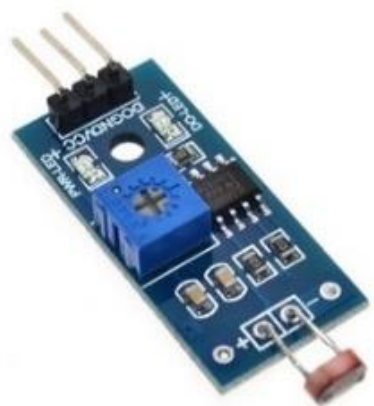

Gambar 2. Modul Sensor Cahaya

Cara kerja dari sensor ini adalah mengubah energi dari foton menjadi elektron, umumnya satu foton dapat membangkitkan satu elektron. Sensor ini mempunyai kegunaan yang sangat luas salah satu yaitu sebagai pendeteksi cahaya pada lampu otomatis. Beberapa komponen yang biasanya digunakan dalam rangkaian sensor cahaya adalah LDR (Light Dependent Resistor), Photodiode, dan Photo Transistor. (Electroino, 2018)

\subsection{Solar Cell}

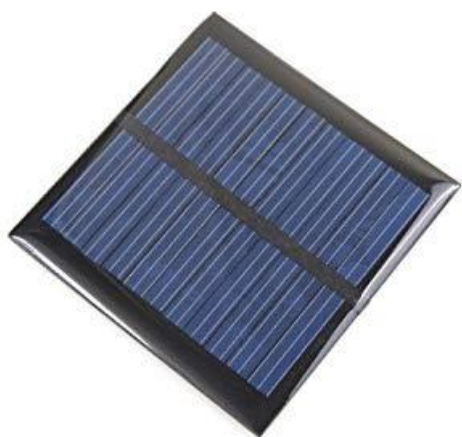

Gambar 3. Solar Cell

Solar Cell adalah suatu komponen yang dapat digunakan untuk mengubah energi cahaya matahari menjadi energi listrik dengan menggunakan prinsip yang disebut efek photovoltaic. Efek photovoltaic itu sendiri adalah suatu fenomena di mana muncul tegangan listrik karena adanya suatu hubungan atau kontak dari dua elektroda, dimana keduanya dihubungkan dengan sistem padatan atau cairan saat mendapatkan energi cahaya. Oleh karena itulah, solar cell sering disebut juga dengan sel photovoltaic (PV). (Kadir, A. E., 1990) 


\section{Analisis Dan Perancangan}

\subsection{Flowchart}

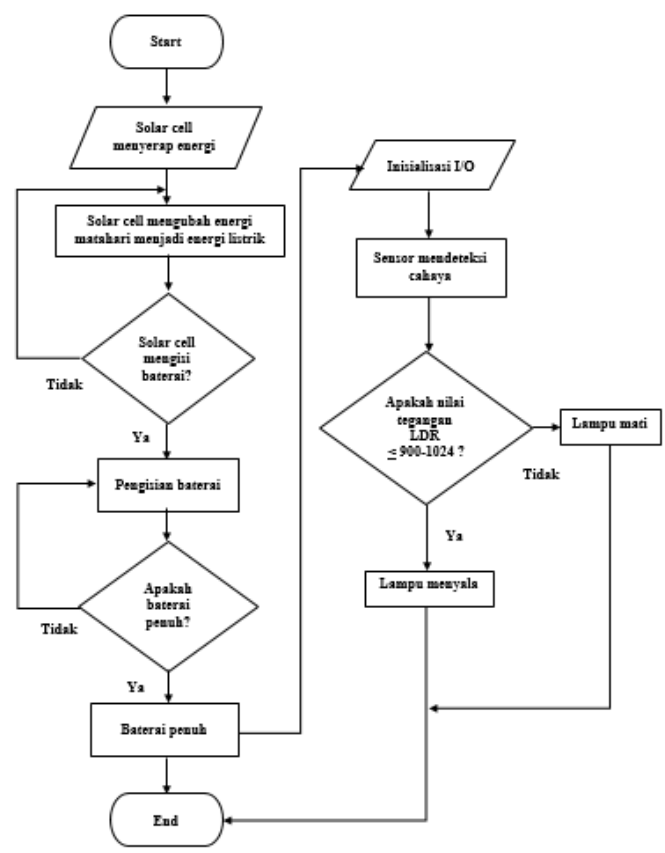

Gambar 4. Flowchart

\subsection{Arsitektur Perangkat Keras}

Arsitektur perangkat keras menggambarkan rangkain perangkat keras secara umum. Rangkaian dibagi menjadi 3 (tiga) unit yaitu: Unit Pengirim, Unit Sensor dan Unit Output.

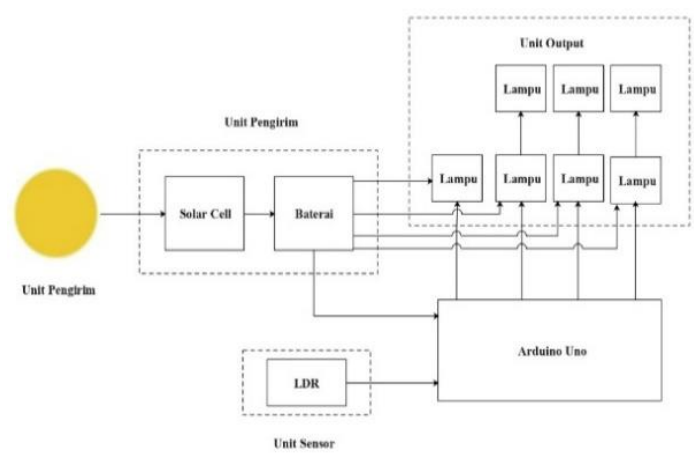

Gambar 5. Arsitektur Perangkat Keras

Seperti terlihat pada gambar diatas, Unit Sensor terdiri dari sensor cahaya (LDR), sensor tersebut dihubungkan pada papan arduino. Sedangkan Unit Pengirim meliputi solar cell, baterai dan matahari sebagai sumber energi. Yang terakhir adalah Unit Output yang meliputi lampu.

\subsection{Skematik Perangkat Keras}

Rancangan skematik perangkat keras menjelaskan rangkaian secara keseluruhan hingga berakhir pada proses kendali lampu.

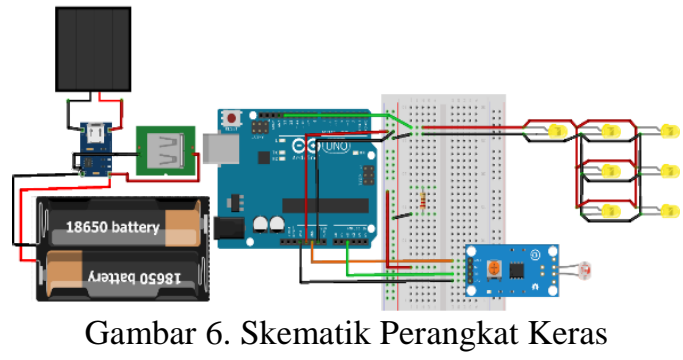

Rancangan Skematik pada gambar diatas dijelaskan sebagai berikut:

1. Sensor LDR dihubungkan ke Arduino menggunakan 3 (tiga) kabel jumper yaitu GND sensor LDR ke pin GND Arduino, VCC sensor ke pin 5V Arduino dan D0 sensor LDR ke pin A2 Arduino.

2. LED dihubungkan ke Arduino menggunakan 2 (dua) kabel jumper yaitu kaki positif LED pin 13 Arduino dan kaki negatif LED ke pin GND Arduino.

3. Kaki kanan resistor dihubungkan ke pin D0 sensor LDR dan kaki kiri resistor ke kaki negatif LED.

4. Solar cell dihubungkan ke modul TP4056, kabel merah solar cell ke IN(+) modul TP4056 dan kabel abu-abu solar cell ke IN(-) modul TP4056.

5. Baterai dihubungkan ke modul TP4056, kabel merah(+) baterai ke pin BT(+) modul TP4056 dan kabel hitam(-) baterai ke BT(-) modul TP4056.

6. Modul DC Charger Booster dihubungkan ke modul TP4056, kabel merah(+) Modul DC Charger Booster ke OUT(+) modul TP4056 dan kabel hitam(-) DC Charger Booster ke OUT(-) modul TP4056.

\section{Implementasi dan pengujian}

\subsection{Implementasi Perangkat Keras}

Perangkat keras yang digunakan dalam pembangunan sistem lampu otomatis dapat dilihat pada Tabel 1 :

Tabel 1. Spesifikasi Perangkat Keras

\begin{tabular}{|l|l|l|}
\hline No & \multicolumn{1}{|c|}{ Perangkat Keras } & \multicolumn{1}{|c|}{ Spesifikasi } \\
\hline 1 & Mikrokontroler & Arduino UNO \\
\hline 2 & Sensor Pendeteksi Cahaya & Sensor LDR \\
\hline 3 & LED & $\begin{array}{l}\text { Mengubah energi } \\
\text { listrik menjadi } \\
\text { energi cahaya }\end{array}$ \\
\hline 4 & Solar Cell & $\begin{array}{l}\text { Mengubah energi } \\
\text { cahaya matahari } \\
\text { menjadi energi } \\
\text { listrik }\end{array}$ \\
\hline 5 & Baterai & $\begin{array}{l}\text { Li-Ion (Lithium- } \\
\text { Ion) }\end{array}$ \\
\hline 6 & Resistor & $330 \Omega$ \\
\hline 7 & Kabel Jumper & Menghubungkan \\
\hline
\end{tabular}




\begin{tabular}{|l|l|l|}
\hline No & \multicolumn{1}{|c|}{ Perangkat Keras } & \multicolumn{1}{|c|}{ Spesifikasi } \\
\hline 8 & Breadboard & $\begin{array}{l}\text { Membuat } \\
\text { rangkaian } \\
\text { elektronik }\end{array}$ \\
\hline 9 & Modul TP4056 & 1 Ampere \\
\hline 10 & $\begin{array}{l}\text { Modul DC Charger } \\
\text { Booster }\end{array}$ & Output 5V \\
\hline
\end{tabular}

\subsection{Implementasi Perangkat Lunak}

Perangkat lunak yang digunakan untuk membangun dan mengimplementasikan sistem adalah sebagai berikut:

1. Sistem Operasi Windows 10 Pro

2. Arduino IDE

3. Fritzing

4. Edraw

\subsection{Implementasi Lampu Penerangan pada Prototype}

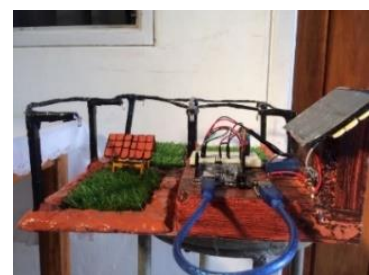

Gambar 7. Implementasi Alat Tampak Depan

Pada gambar 7 implementasi alat jika dilihat dari depan.

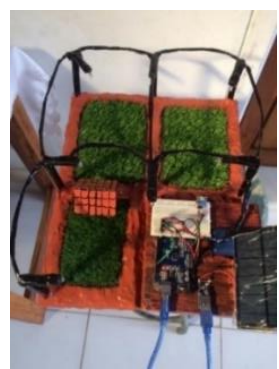

Gambar 8. Implementasi Alat Tampak Atas

Pada gambar 8 implementasi alat jika dilihat dari atas.

\subsection{Hasil Pengujian}

\subsubsection{Pengujian Sensor LDR}

Tabel 2. Pengujian Sensor Cahaya

\begin{tabular}{|c|c|c|c|}
\hline No & Waktu & $\begin{array}{c}\text { Nilai Sensor } \\
\text { Cahaya }\end{array}$ & Output \\
\hline 1 & 06.00 & $\begin{array}{l}24-25 \Omega \text { nilai } \\
\text { tegangan LDR } \\
\text { yang terbaca } \\
\text { di arduino }\end{array}$ & $\begin{array}{l}\text { Lampu } \\
\text { penerangan } \\
\text { persawahan } \\
\text { mati }\end{array}$ \\
\hline 2 & $13.00-17.00$ & $\begin{array}{l}120-800 \Omega \\
\text { nilai tegangan } \\
\text { LDR yang } \\
\text { terbaca } \quad \text { di }\end{array}$ & $\begin{array}{l}\text { Lampu } \\
\text { penerangan } \\
\text { persawahan } \\
\text { mati }\end{array}$ \\
\hline
\end{tabular}

\begin{tabular}{|l|c|l|l|}
\hline No & Waktu & $\begin{array}{l}\text { Nilai Sensor } \\
\text { Cahaya }\end{array}$ & Output \\
\hline & & arduino & \\
\hline 3 & $18.00-19.00$ & $\begin{array}{l}900-1000 \Omega \\
\text { nilai tegangan } \\
\text { LDR yang } \\
\text { terbaca di } \\
\text { arduino. }\end{array}$ & $\begin{array}{l}\text { Lampu } \\
\text { penerangan } \\
\text { persawahan } \\
\text { menyala }\end{array}$ \\
\hline 4 & $19.00-04.00$ & $\begin{array}{l}1023-900 \text { nilai } \\
\text { serial monitor } \\
\text { LDR }\end{array}$ & $\begin{array}{l}\text { Lampu } \\
\text { penerangan } \\
\text { persawahan } \\
\text { menyala }\end{array}$ \\
\hline
\end{tabular}

Berdasarkan pada Tabel 2 pengujian sensor LDR dapat dilihat bahwa nilai sensor cahaya akan berubah sesuai dengan intensitas cahaya.

\subsubsection{Pengujian Solar Cell}

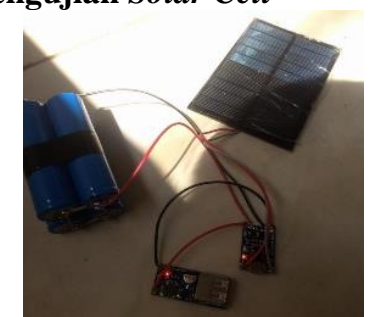

Gambar 9. Pengujian Solar Cell (a)

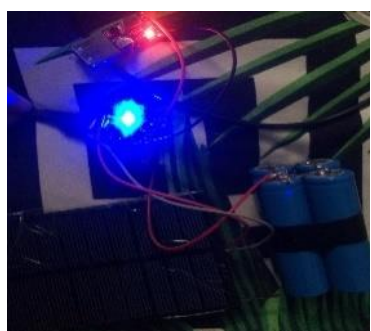

Gambar 9. Pengujian Solar Cell (b)

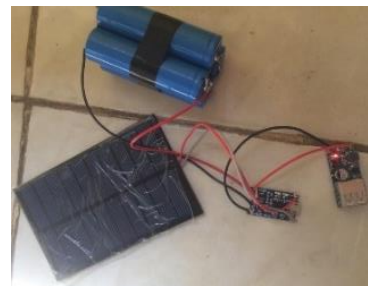

Gambar 9. Pengujian Solar Cell (c)

Dilihat pada gambar 9. Pengujian Solar Cell(a) sebelah kiri indikator modul TP4056 menyala berwarna merah menandakan solar cell sedang mengisi baterai pada saat terkena cahaya matahari. Gambar 9. Pengujian Solar Cell (b) sebelah kanan pada indikator modul TP4056 menyala berwarna biru maka baterai sudah terisi penuh. Sedangkan pada Gambar 9. Pengujian Solar Cell (c) indikator modul TP4056 mati menandakan solar cell tidak mengisi baterai karena tidak terkena cahaya matahari. 


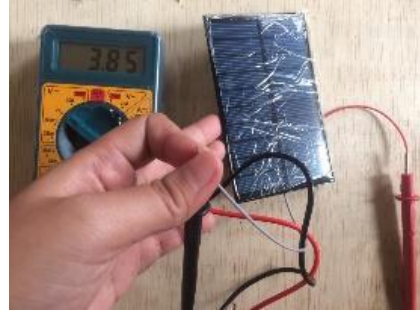

Gambar 10. Pengujian Tegangan Solar Cell

Tabel 3. Pengujian Solar Cell

\begin{tabular}{|c|c|c|c|c|c|c|}
\hline \multirow[b]{2}{*}{ No } & \multirow{2}{*}{ Jam } & \multicolumn{3}{|c|}{ Pengujian ke- } & \multirow{2}{*}{$\begin{array}{l}\text { Rata- } \\
\text { Rata }\end{array}$} & \multirow{2}{*}{$\begin{array}{c}\text { Standard } \\
\text { Deviasi }\end{array}$} \\
\hline & & 1 & 2 & 3 & & \\
\hline 1 & 06.00 & $\begin{array}{c}3,85 \\
\mathrm{~V}\end{array}$ & $\begin{array}{c}4,1 \\
\mathrm{~V}\end{array}$ & $\begin{array}{c}4,1 \\
\mathrm{~V}\end{array}$ & $\begin{array}{c}4,01 \\
V\end{array}$ & 0,01 \\
\hline 2 & 09.00 & $5 \mathrm{~V}$ & $\begin{array}{l}5 \\
V\end{array}$ & $\begin{array}{l}5 \\
V\end{array}$ & $5 \mathrm{~V}$ & 0 \\
\hline 3 & 12.00 & $5 \mathrm{~V}$ & $\begin{array}{l}5 \\
V\end{array}$ & $\begin{array}{l}5 \\
V\end{array}$ & $5 \mathrm{~V}$ & 0 \\
\hline 4 & 15.00 & $\begin{array}{l}4,1 \\
\mathrm{~V}\end{array}$ & $\begin{array}{c}4,1 \\
\mathrm{~V}\end{array}$ & $\begin{array}{l}4,1 \\
\mathrm{~V}\end{array}$ & $4,1 \mathrm{~V}$ & 0 \\
\hline 5 & 18.00 & $0 \mathrm{~V}$ & $\begin{array}{l}0 \\
\mathrm{~V}\end{array}$ & $\begin{array}{l}0 \\
\mathrm{~V}\end{array}$ & 0 & 0 \\
\hline
\end{tabular}

Berdasarkan pada Tabel 3 pengujian pengukuran tegangan Solar Panel yang berbeda selama 3 kali pengujian didapatkan pada salah satu pengujian yaitu pada pukul 06.00 menunjukkan hasil tegangan Solar Panel yang berbeda hal ini dipengaruhi oleh faktor alam dan cuaca seperti mendung dll. Pada pengujian selanjutnya didapatkan nilai rata-rata yang sama dan standard deviasinya nol (0) hal ini menunjukkan bahwa datanya seragam dan stabil sehingga Solar Panel yang digunakan pada sistem ini berfungsi dengan baik dan didapat waktu yang paling optimal untuk proses Charging yaitu antara jam 09.00 - jam 15.00 .

Tabel 4. Pengujian Kapasitas Keluaran Solar Cell

\begin{tabular}{|c|c|c|c|}
\hline Waktu & V (Volt) & I (mA) & Watt \\
\hline 06.30 & 1.2 & 10 & 0.012 \\
\hline 07.00 & 6.3 & 64 & 0.414 \\
\hline 07.30 & 6.5 & 69 & 0.460 \\
\hline 08.00 & 7 & 75 & 0.615 \\
\hline 08.30 & 7 & 77 & 0.63 \\
\hline 09.00 & 8 & 79 & 0.651 \\
\hline 11.00 & 8.2 & 80 & 0.67 \\
\hline 13.30 & 8.5 & 83 & 0.736 \\
\hline 14.00 & 7.1 & 78 & 0.502 \\
\hline 15.30 & 6 & 69 & 0.5 \\
\hline 17.00 & 5.4 & 60 & 0.421 \\
\hline 18.30 & 5 & 55 & 0.4 \\
\hline 19.00 & 4.5 & 50 & 0.382 \\
\hline
\end{tabular}

\begin{tabular}{|c|c|c|c|}
\hline Waktu & V (Volt) & I (mA) & Watt \\
\hline 20.00 & 4.3 & 47 & 0.352 \\
\hline 20.30 & 4.2 & 45 & 0.313 \\
\hline 21.00 & 4.1 & 44 & 0.3 \\
\hline 21.30 & 4.1 & 42 & 0.213 \\
\hline 22.00 & 4 & 41 & 0.2 \\
\hline
\end{tabular}

Berdasarkan pada Tabel 4 adalah hasil dari pengujian kapasitas keluaran dari solar cell yang telah dilakukan pada pukul 06.00 pagi sampai pukul 22.00 malam.

\subsubsection{Pengujian Baterai}

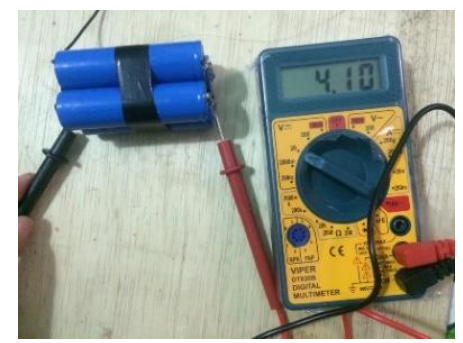

Gambar 11. Pengujian Tegangan Baterai

Dilihat pada gambar 11 Pengujian Baterai dapat dilihat bahwa tegangan baterai menunjukkan nilai yang normal, jika nilai 0 baterai tersebut rusak dan tidak dapat digunakan.

Tabel 5. Tegangan Input Minimum

\begin{tabular}{|c|c|}
\hline Jumlah Baterai (n) & $\begin{array}{c}\text { Tegangan Input } \\
\text { Minimum (V) }\end{array}$ \\
\hline 1 & 6,2 \\
\hline 2 & 10,4 \\
\hline 3 & 14,6 \\
\hline 4 & 18,8 \\
\hline
\end{tabular}

Tegangan minimal pada Tabel 4 dimaksudkan supaya rangkaian charger dapat meregulasi tegangan pengisian baterai dengan baik.

Tabel 6. Pengujian Baterai

\begin{tabular}{|c|c|c|c|c|}
\hline $\begin{array}{c}\text { V in } \\
(\mathbf{V})\end{array}$ & $\begin{array}{c}\text { V awal } \\
(\mathbf{V})\end{array}$ & $\begin{array}{c}\text { V akhir } \\
(\mathbf{V})\end{array}$ & $\begin{array}{c}\text { Arus } \\
\text { Charging } \\
(\mathbf{m A})\end{array}$ & $\begin{array}{c}\text { Waktu } \\
\text { (menit) }\end{array}$ \\
\hline 18,3 & 3,71 & 3,89 & 45,1 & 95 \\
\hline 18,6 & 3,80 & 3,95 & 45,7 & 77 \\
\hline 16,7 & 6,93 & 7,47 & 89,5 & 69 \\
\hline 14,3 & 7,47 & 7,54 & 107,9 & 28 \\
\hline
\end{tabular}

Hasil pengujian baterai menggunakan solar cell dapat dilihat pada Tabel 6 Solar cell hanya mampu melakukan pengisian baterai lithium-ion maksimal 3 buah, karena tegangan output maksimal yang dihasilkan kurang dari batas tegangan input minimum charger untuk 4 buah 
baterai yaitu sebesar 18,8 V.

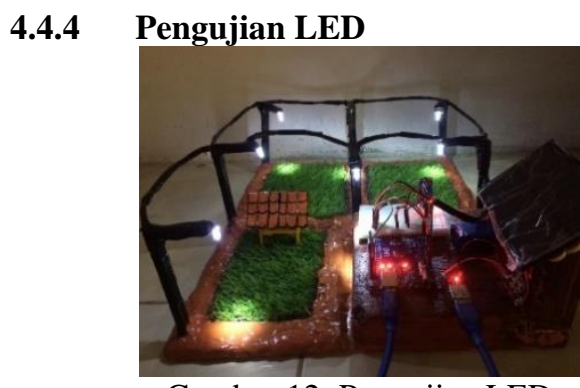

Gambar 12. Pengujian LED

Hasil dari pengujian LED yang telah diprogram dan disambungakan didapatkan data yang sesuai, sehingga semua LED dapat menyala.

\section{Kesimpulan dan Saran}

\subsection{Kesimpulan}

Berdasarkan implementasi dan pengujian yang telah dilakukan terhadap prototype lampu penerangan persawahan otomatis tenaga solar cell maka dapat diambil kesimpulan unjuk kerja dari Prototype Lampu Penerangan Persawahan Otomatis Menggunakan Solar Cell dan Sensor Cahaya. Solar Cell dan Sensor Cahaya berperan penting dalam penerangan persawahan pada malam hari. Lampu penerangan ini menggunakan solar cell sebagai sumber energi, sumber energi yang sudah diubah menjadi energi listrik kemudian disimpan dibaterai sebagai cadangan energi. Lampu penerangan ini menggunakan sensor cahaya yang akan otomatis menyala pada saat malam hari dan akan otomatis mati pada siang hari sehingga petani tidak harus menekan tombol ON/OFF saat menyalakan ataupun mematikan lampu. Solar cell dapat mengisi baterai Li-Ion (Lithium-Ion) berjumlah 1-4 buah. Waktu yang paling optimal untuk proses charging solar cell yaitu antara jam 09.00 - jam 15.00. Nilai tegangan LDR yang terbaca di arduino $24-800 \Omega$ maka kondisi lampu LED akan mati, dan jika nilai tegangan LDR yang terbaca di arduino 900 - 1024 $\Omega$ lampu LED akan menyala.

\subsection{Saran}

Pemanfaatan cahaya matahari akan lebih maksimal bila solar cell yang digunakan dapat otomatis mengikuti arah datang cahaya.

\section{Daftar Pustaka :}

Anhar. W, dkk. 2018. Perhitungan Lampu Penerangan Jalan Berbasis Solar System. Jurnal Sains Terapan. Vol 4, No 1.

Adisanjana, Nyoman Ngurab dan Made Murna. 2019. Rancang Bangun Sistem Lampu
Otomatis Menggunakan Sensor Light Dependent Resistor (LDR) Untuk Menciptakan Konsep Kampus Hemat Energi (Studi Kasus: Universitas Dhyana Pura Bali. Vol. 2, No. 2.

Fitri, Dini Siti Fatimah dan Suhendra Akbar. 2017. Perancangan Pengendali Lampu Otomatis Berbasis Arduino Nano. Jurnal Algoritma Sekolah Tinggi Garut. Vol. 14, No. 2.

Hikawan, Sugik Rizky dan Eko Agus Suprayitno. 2018. Rancang Bangun Lampu Penerangan Jalan Umum (PJU) Menggunakan Solar Panel Berbasis Android. ELINVO. Vol. 3, No. 1, hlm 9-17.

Ihsanto, Eko dan Muhamad Dawud. 2016. Sistem Monitoring Lampu Penerangan Jalan Umum Menggunakan Mikrokontroler Arduino dan Sensor Ldr dengan Notifikasi Sms. Jurnal Teknologi Elektro. Vol 7, No 2.

Julisman, Andi, dkk. 2017. Prototipe Pemanfaatan Panel Surya Sebagai Sumber Energi Pada Sistem Otomasi Atap Stadion Bola. Jurnal Online Teknologi Elektro. Vol 2, No 1.

Muzawi, Rometdo, dkk. 2018. Prototype Pengontrolan Titik Fokus Panel Surya Terhadap Energi Matahari Secara Otomatis Pada SMTMIK-AMIK Riau. Jurnal Inovtek Polbeng. Vol 3, No1.

Pardede, Akim Manaor Hara, dkk. 2017. Implementasi Pengendalian Lampu Otomatis Berbasis Arduino Menggunakan Metode Fuzzy Logic. Techsi Vol. 9, No. 2.

Prasetyo, Mugi Alan dan Rachmat Aulia. 2020. Prototype Penerangan Lampu Taman Otomatis Menggunakan Arduino Uno. CESS (Journal of Computer Engineering, System and Science). Vol. 5, No. 1.

Sugiyanto, Muchammad Abrori. 2017. Pemanfaatan Solar Cell Sebagai Sumber Energi Alternatif dan Media Pembelajaran Praktikum Siswa Di Pondok Pesantren "Nurul Iman" Sorogenen Timbulharjo, Sewon, Bantul, Yogyakarta Menuju Pondok Mandiri Energi. Jurnal Bakti Saintex. Vol.1, No.1.

Somadani, Dede dan Ade Hari Ginanjar. 2018. Prototipe Penerangan Jalan Umum (PJU) Pintar Berbasis Arduino Menggunakan Solar Panel, Sensor HC-SRO4 dan Sensor LDR. Seminar Nasional Sains dan Teknologi 2018.

Sutono dan M F Wicaksono. 2018. Lampu PJU Otomatis. Jurnal Sistem Komputer. Vol. 7, No. 1, hlm. 17-20.

Sutrisno, dkk. 2019. Perawatan Listrik Tenaga Surya Untuk Penerangan Jalan Desa Bagi Karangtaruna Desa Glanggang Kecamatan Pakisaji Malang. Jurnal Graha Pengabdian. Vol 1, No 1.

Winata, Ryan Ardi. 2018. Prototype Kendali Otomatis Penerangan Taman dengan Tenaga 
Volume 7, Edisi 1, November 2020

Surya Berbasis Arduino. Jurnal TeknoSAINS Seri Teknik Elektro. Vol 1 No 1.

Yuliza dan Ardiansyah. 2016. Perancangan Lampu Taman Solar Cell Otomatis Untuk Menggunakan Microcontroller Arduino Uno. Jurnal Teknologi Elektro. Vol 7, No 1.

\section{Lampiran}
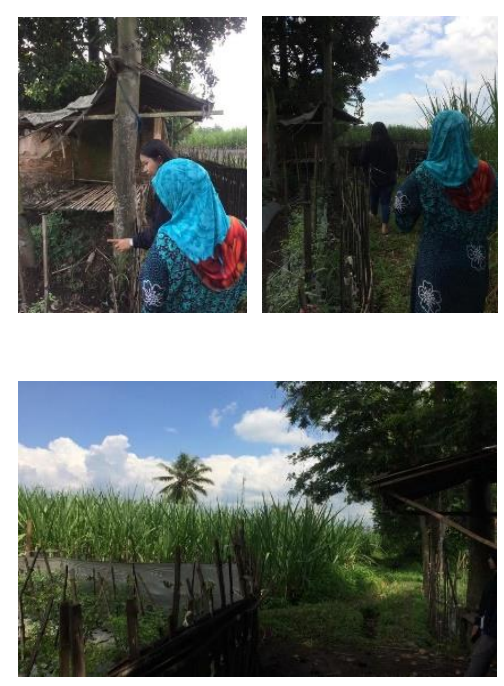